\title{
Preserving Ethnicity- A Study of the Tai-Phake community of Namphake village, Dibrugarh District (Assam)
}

\author{
Priyanka Kakoti \\ (Department of English, Dr Radha Krishnan School of Arts, Commerce and Science, Assam, India)
}

\begin{abstract}
The Tai-Phakes who belong to the great Tai race entered Assam in the $18^{\text {th }}$ century and gradually settled in nine villages in Tinsukia and Dibrugarh districts. Namphake village situated few kilometers from the town of Naharkatiya in Dibrugarh district is one of the earliest Tai-Phake villages. Just like any other community, the Tai-Phake community has also been influenced by modernism, however, it has been able to maintain its ethnicity with respect to marriage, dress, family, religion. This has been possible due to the attitude of the people towards their culture and also due to the strong desire and efforts of these people to preserve their culture in spite of the effects of modernization and globalization.
\end{abstract}

Key words: community, culture, ethnicity, race, Tai-Phake

\section{Introduction}

The Tai-Phakes entered Assam in 1775 A.D during the reign of the Ahom king Lakshmi Sinha (17691780 A.D) and settled at Nangtao of present Arunachal Pradesh. They belong to the great Tai race. Ethnically the belong to the Mongoloid tribe and linguistically the belong to the Tibeto- Chinese families. They settled in Arunachal Pradesh for a few years and during the British rule they gradually entered Assam and started living in small groups in Dibrugarh and Tinsukia districts, where they are still found now. Presently they live in nine villages of Dibrugarh and Tinsukia districts which are as follows :- Namphake and Tipamphake on the bank of the river Buridihing of Naharkatiya area of Dibrugarh district, and Mounglang, Man Mou, Bor Phake, Man Long or Long Phake, Ningam Phake or Ningam, Nonglai and Phaneng in Ledo-Margherita area in Tinsukia district.

Throughout history it has been the concern of all the ethnic groups to maintain their ethnicity irrespective of the globalization which has affected each and every community. Irrespective of modernization peeping in each and every household, it has been observed that the Tai Phake community has been able to preserve its ethnicity. This can be viewed as one of the main reasons why so many researches have been made on this community residing in Dibrugarh district.

This paper aims to explore the institutions of marriage, religion and family of the Tai-Phake community of Namphake village of Dibrugarh district and how ethnicity has been preserved by the Tai Phakes of this village with respect to these institutions.

\section{Area Of Study}

The present study has been conducted on the Tai Phake people living in Namphake village, situated at a distance of about $3 \mathrm{kms}$ from the Naharkatiya town of Dibrugarh district.

\section{Methodology of the study}

Method: Considering the nature of the data collected, descriptive method has been adopted in the present study. Population: The population of this study comprised of 50 households out of 90 households present in Namphake village.

Sample: 50 households of Namphake village have been selected as sample for the study. Simple random sampling has been adopted for selecting the sample.

\section{Tools used for collection of data:}

For the purpose of this study, a well organized structured questionnaire schedule has been used for the collection of the data from the sample respondents.

\section{Collection of data}

In order to collect the data, an interview schedule was prepared. Respondents were interviewed carefully on a number of questions and supplementary questions through face to face interactions and their answers/replies were noted down for the composition of the literature of the paper. 


\subsection{Marriage}

\section{Analysis of data collected}

Marriage within the community is a basic feature of the Tai-Phake community and this is still being practiced in order preserve their ethnicity. Although marriage out caste is not prohibited, certain rituals are a must even in case of an inter caste marriage. According to Chaineyp Chakap, the village headman, the presence of a " bou khai' or a " ghai khuta" is essential even if an inter caste marriage takes place. The egg plays an important role in the 'horai' which is offered during marriage. Throughout ages the groom has met the marriage expenses on both sides and this is prevalent till date.

In case of an elopement a penalty has to be paid. The amount of the penalty is decided by the villagers. They do not have the system of child marriage.

\subsection{Family}

The Tai-Phakes live in nuclear families as they believe that harmony and understanding among family members can be maintained in this type of a family system. Patriarchal family system is followed and the son inherits his father's property. However, in case of a spinster, the daughter is also given a share of the property. Married girls are not given a share of the father's property.

The data shows that as many as $80 \%$ of the sample households live in nuclear families. As soon as the son gets married, he shifts to another house to set up his own household. Including parents, the average family size is about 5 to 6 members. In spite of living in nuclear families, these people have preserved their culture. There is at least one handloom in every household and girls in spite of attending school or college are taught to weave their traditional dress.

The Tai Phake women wear colourful dresses woven by them. Their outfit consists of an ankle-long skirt (Chin), a blouse open at the front (Nang Wat) and fastened around the armpits and a girdle (Chai Chin) to tighten the skirt around the waist. The female child wears a skirt (Chin) and a blouse. A white turban (Phahu) is worn by the women folk on individual preference. The colours of their dresses are expressive of their ages. The girls wear white sarongs; women stripped red, yellow and green sarongs and old women deep purple and blue sarongs with stripes. The men wear lungis known as phanoot, a kurta, and a folded chadar.

According to the village headman, wearing the traditional dress in the village is compulsory. He said " It is compulsory to wear the traditional dress in the village not just during ceremonies and functions but otherwise on usual days as well. Nowadays children go out of the village to study but once they are back home they have to wear our traditional dress. This is essential to maintain our identity. We mix up with other communities but we cannot leave our culture. This is one of the main reasons why we do not want to marry girls from other communities into our village. They do not know to weave our traditional dress. Even if they are taught, they are not experts compared to our girls who have learnt it since their childhood days. It is in our genes."

\subsection{Religion}

Religion, by prescribing a set of specific beliefs, attitudes and practice exerts an influence in shaping one's personal life style as well as one's social behaviour.

The Tai Phake people are followers of Buddhism. The Buddhist monastery at Namphake village was established in 1850. The monastery has mosaic and tiled floors. The head priest of the Namphake Buddhist temple is known as 'vante'. The affairs of the monastery are run by the monks with active cooperation of the people. The people provide food and clothes to the monks. There is a modern-equipped guest house near the Vihar premises.

Some of the important religious festivals of the Tai-Phake community are as follows:-

Poi Sang Ken or Pani Bihu- the Tai-Phake calendar starts with a new year from the first day of the festival and it is celebrated for the following three days. During this festival, the villagers wash the idol of the Buddha and play with water.

Buddha Purnima- is celebrated after Poi Sang Ken on full moon day.

Barsha Bash- during this festival, the Buddhist monk undertakes fast for three months from the full moon of 'ahara' to the full moon of 'ahin'.

Poi Akwa- during this festival, the Buddhist monks gather in a particular place and pray to forgive them for their sins.

Poi Ma ko Chum- during this festival which is celebrated in the month of February, fire is set on 'mejis' on the river bank.

\subsection{Death}

As far as the last rites of the dead are concerned, the Tai-Phakes have their own beliefs. The dead is either buried or cremated depending on the nature of the death. In case of accidental deaths, the dead body is not 
allowed to be brought inside the village. The body is buried outside the village premises and all funeral rites are also performed outside the village rituals.

\subsection{Factors responsible for preservation of ethnicity}

The following factors are responsible for preservation of ethnicity by the Tai-Phake community:-

- Attitude of the people towards their culture.

- Strong desire on the part of both the adults as well as the youngsters to preserve their culture.

- Ability of the people to judge themselves and the effect of modernism on their culture.

- Adoption of new techniques but still adhering to their age old beliefs.

- Not challenging traditional customs and practices.

\section{Conclusion}

Like other communities, the Tai-Phake community has also been influenced by modernism in various aspects such as economic, political, social and cultural. Adoption of the modernity of the Buddhist cultures from neighbouring Thailand and Myanmar has definitely affected these people. The changes are prominently noticed in daily household items like- television, computer, radio, electricity, telephone, toiletries and so on. In spite of these effects of modernism and in spite of living just a few kilometers away from the Naharkatiya town, the TaiPhake community has been successful in maintaining its ethnicity and in preserving its distinct identity through ages.

\section{Books:}

\section{References}

[1] K.C Borah, The Tai-Phakes A Demographic Profile (Dibrugarh, Department of Economics, Dibrugarh University, 2007)

[2] Supriti Phukan, The Phakes (Guwahati, Students' Stores, 2005) 